\title{
Voting in the European Union - Central Europe's Lost Voice
}

\author{
ONDŘEJ SCHNEIDER
}

CESIFo Working PAPER No. 2454

CAtegory 2: Public Choice

NOVEMBER 2008

\footnotetext{
An electronic version of the paper may be downloaded

- from the SSRN website: www.SSRN.com

- from the RePEc website:

- from the CESifo website:

www.RePEc.org

www.CESifo-group.org/wp
} 


\title{
Voting in the European Union - Central Europe's Lost Voice
}

\begin{abstract}
Ten Central European countries became members of the European Union in the years 2004 2007. They constitute $20 \%$ of the EU's total population; and even though their economic output is much lower, it rises dynamically. New members' impact on the EU policies has nevertheless been limited. This is due not only to the arcane voting rules within the EU, but also to the lack of a common agenda among the Central European countries. Our paper illustrates that the new members rarely vote together and that their influence is thus fairly limited. We argue that as the EU seemingly lacks energy to implement further reforms that would stimulate its economy, impetus for change may come from Central European countries. To that end, however, they have to coordinate their voting and become a more coherent voting group than they are now.
\end{abstract}

JEL Code: J08, J51, K31.

Keywords: European Union, voting system, European Council, new member states.

\author{
Ondřej Schneider \\ Institute of Economic Studies \\ Charles University Prague \\ Opletalova 26 \\ 11000 Prague \\ Czech Republic \\ schneider@fsv.cuni.cz
}

This paper was written while the author was a resident scholar at the Centre for European Policy Analysis in Washington DC. The generous support from the CEPA and constructive discussions with Wess Mitchell of CEPA helped to improve the paper and are gratefully acknowledged. Financial support from the GAČR grant number 402/08/0501 is gratefully acknowledged. All remaining errors are the authors' responsibility. 


\section{Introduction}

Central European countries ${ }^{1}$ have traveled a long way from their underdeveloped, grey and autarky economies in the late 1980's. Ten out of the eleven countries that can be qualified as "former socialist countries" now boast membership in the EU, NATO, some of them are also OECD members, already "graduated" from the World Bank program and shift to the donor status. Slovenia uses the European currency - the euro - since 2007, Slovakia is expected to join the currency in 2009. All countries in the region grow fast - a sad exception being Hungary.

The transition from the centrally planned economies to a market system has, thus, raised wealth of CEE's citizens and brought these countries, once isolated within the autarkic Soviet bloc, into the fore of policy making, at least in the European context. One may assume that the shared history and economic problems would push these countries together, so they would share the same positions vis-à-vis the main European policies.

In this paper, we test this hypothesis analyzing the data on decision making in the European Union. We discuss complex decision making rules within the EU and we illustrate the relative power of the CEE countries. In the second part of the paper we analyze voting patterns of the CEE countries in the main EU's decision-making body - the European Council. We show that the CEE countries raise objections only occasionally and that they almost never vote together. This finding suggests that either there is no shared agenda for the CEE countries within the EU or that they do not cooperate for some other reasons.

\section{CEE in the EU: Political Economy and Decision Making}

\section{A. Decision making in the EU}

The decision-making process within the European Union is very complex. The main institutions within the EU are the European Commission (EC), the European Parliament (EP), the European Councils (there are nine of them plus

\footnotetext{
${ }^{1}$ We use term CEE as to describe the following eleven countries: Bulgaria, Croatia, Czech Republic, Estonia, Hungary, Latvia, Lithuania, Poland, Romania, Slovakia and Slovenia. All but Croatia are members of the EU, hence the term EU10.
} 
the European Council of heads of states) and the European Central Bank (ECB). Authorities of these institutions often overlap making the decision process even more complicated. See Wallace, Wallace and Pollack (2005) for more detailed analysis of the EU voting system.

Decision making within the EU is so complex because it must accommodate national interest of 27 countries. The EU is a club of sovereign states whereby each country, no matter how small, requires at least a symbolic power over the EU's decisions. This renders simple voting procedures not very useful and creates conditions for the current plethora of various voting methods, supermajorities, double or even triple-majorities, and so on.

First of all, the European Commission and the ECB do not really vote, they always reach "consensus" which makes analysis of their decision process extremely difficult, as it is not known how the consensus was molded what was offered and what was agreed as a compensation for potentially agitating countries. $^{2}$

The executive branch of the European Union - the European Commission headed since November 2004 by former Portuguese prime minister Jose Manuel Barroso - has adopted a more careful approach in proposing new legislation and seeks strong coalitions of countries before it proposes any change (notable exemption being the planned directive on cutting caremission limits for cars that infuriated the German industry representatives, government and even the German commissioner Gunter Verheugen - see, for example http://www.euractiv.com/en/transport/eu-gets-cold-feet-capping-caremissions/article-161111). It also pursues more negotiating with the European Parliament, but it is not, by any measure, paralyzed. It is yet to vote on single agenda item and still gets most of new legislation through very quickly.

The European Parliament does vote, but it is rather a weak EU institution, even though it is the only directly elected EU institution. The EP shares its legislative power with the Council and it can vote only on those issues transferred to it by national parliaments. Namely, the EP lacks the legislative initiative which is rare for a parliament. The EP does not appoint the European Commission President, either. This power belongs to the European Council. The European Parliament can, on the other hand, veto the European Commission appointment and its intervention brought down the Commission of president Santer in 1995 after allegations of corruption (the Commission

\footnotetext{
${ }^{2}$ With respect to the ECB, we discuss the "dynamic consensus" below.
} 
resigned en masse in March 1999). The Parliament also decides on the EU budget, which is important but limited in its size of about $1 \%$ of the EU's GDP.

In this paper, thus, we concentrate on the Council of the European Union (or the Council), which is the main decision-making body within the European Union's institutional architecture. It consists of representatives of all national governments and it has the legislative powers usually reserved for parliaments. The Council discusses European Commission's proposals and if it approves them, they become a part of the mandatory acquis communautaire. In some areas, the Council dominates the parliament and only consults it but the Parliament cannot amend the proposals. This is the case mostly in foreign and security policies where member states are more worried about their national sovereignty. In other areas, the EC proposal must be approved by the European Parliament as well. But the Council remains the main decisionmaking body of the European Union, where the most power is concentrated.

In the following chapters, we first briefly discuss European Central Bank decision process, as it is importantly influenced by the CEE countries' actual or expected membership. Then we turn to the Council and discuss its various decision making procedures.

\section{B. European Central Bank}

European Central Bank oversees the most centralized policy within the European Union - monetary policy where member countries share the same currency, they apply the same interest rates and their financial systems become ever more integrated. Eurozone consisted of eleven countries upon its establishment in 1999 (Germany, France, Belgium, Netherlands, Luxembourg, Italy, Spain, Portugal, Austria, Ireland and Finland). It was later joined by Greece, and in 2007 by Malta, Cyprus and Slovenia. In May 2008, Slovakia was formally endorsed as the $16^{\text {th }}$ member of the Eurozone and it is expected to become a member in January 2009.

Slovakia's entry to the Eurozone will trigger an overhaul of the voting system in the ECB - see Frenkel and Fendel (2003). Until 2008, the ECB's Governing Council consists of six members of the Executive board (appointed by "common accord of the governments of the member States... on recommendation from the Council after it has consulted the European Parliament and the Governing Council") and by governors of member states' central banks (currently 15 members). 
When the membership increases to 16 countries, new system should be ushered in whereby the total number of votes is capped at 21 . Six votes are casted by the members of the Executive board. Remaining fifteen votes are to be distributed among governors of member states' central banks. Initially, as there are 16-18 member states, governors will be split into two groups. The first group would consist of five largest Eurozone member countries (Germany, France, Italy, Spain and the Netherlands) ${ }^{3}$ that will vote on each occasion. Remaining eleven-thirteen member states would get only 10 votes and the voting rights would rotate among them to ensure equal voting rights for each country. When there are more then 19 members of the Eurozone, the first group of five large countries will see its number of votes to drop to four.

These changes in the voting system may explain the ECB's reserved position vis-à-vis new members (the ECB famously turned down Lithuania application in 2006 as its inflation was $0.1 \mathrm{pp}$ above the threshold set by the Maastricht criteria $\left.^{4}\right)$. The ECB has just one instrument - interest rate - to steer the EU's economic policy. However, the more countries join the ECB, the more diverse they will be and the more complicated it will be to find an interest rate that would respond to these countries' economic needs (see de Grauwe (2005) for a discussion).

It remains to be seen how the ECB voting pattern will develop under the new voting system. Currently, the ECB does not, formally, take vote. Instead, it applies so called "dynamic consensus" to take any decision. Under this method, the President of the ECB summarizes positions of majority of the Governing Council, proposes the decision and "invites" remaining members to join the majority. As the decision can be, formally, taken by a simple majority, the remaining members routinely join the decision, as to demonstrate the ECB's unity.

Under the new voting system, not all countries will take part in formal voting, as their voting rights will "rotate". This may not be a problem, as long as informal decision making process will keep countries involved in the decision making. Moreover, large member countries may not become to "rotate" for a long time. The first group of 5 countries will hold 5 votes until a $19^{\text {th }}$ member country joins the Eurozone, a distant perspective now. Moreover, large

\footnotetext{
${ }^{3}$ The fifth "large country" place is clearly reserved for the UK, should it ever join the Eurozone.

${ }^{4}$ The ECB and the Council voiced concerns about sustainability of the Lithuanian inflation, the view that might have been vindicated by a surge in the inflation in Lithuania that stood at $11.3 \%$ in March 2008, way above the Eurozone's inflation rate.
} 
countries, together with the Executive Board members who often hail form these large countries (current members are from France, Germany, Italy, Spain, Austria and Greece, in the previous Board members were from France, Germany, Italy, Spain, the Netherlands and Finland), will hold majority in the Eurozone consisting of 16-18 members. The balance will turn to "second rank" countries when a $19^{\text {th }}$ member joins the Eurozone.

\section{C. $\quad$ Voting systems in the European Council}

The voting procedures in the European Council are not straightforward, to say the least. Different issues are subject to different voting methods and these methods evolve over time. The Council votes in one of three ways; unanimity, simple majority or qualified majority The unanimity rule now applies only in particularly sensitive areas such as asylum, taxation and the common foreign and security policy. It may be further reduced by the Lisbon Treaty, if it is approved by all 27 member states. In most cases the Council votes on issues by qualified majority voting. The EU's method of qualified majority voting is very sophisticated as it applies three different majorities. First, countries have different number of votes (see table below) and a minimum of 255 votes out of $345(74 \%)$ must be casted in favor of a proposal. Second, the proposal must be further approved by a majority of member states (sometimes even a twothird majority). Last, the "demographic safety net" is applied, when the qualified majority must represents at least $62 \%$ of the population of the Union.

Many EU insiders were afraid that this finely balanced and inherently complicated voting system may be unfit for an enlarged European Union. Indeed, the fear of "stalemate" and dysfunctional decision-making as the EU becomes a much more heterogeneous club of 27 countries was the most frequent rationale mentioned as the European Convent, a special body headed by a former French president Giscard d'Estaing, attempted to change the decision making process in its draft of the European Union's Constitution.

The argument was that original European institutions, established in Treaty of Rome of 1957, were designed for a club of six countries and adopted to the Union of fifteen countries that became members by 1994. These fifteen, with a possible exception of Greece, were rather homogenous Western European countries, long honed in intergovernmental negotiations and with a shared "responsibility" for the European project (even though different countries might have projected different European Union visions). However, the 
Constitution draft was, eventually, defeated in referendums in Germany and the Netherlands in 2005. A modified Treaty of Lisbon (see below) then suffered the same fate in 2008 in Ireland. The European Union has, thus, enlarged to 27 members and still uses principles of decision making from the 1957 Treaty of Rome that were adjusted in 2001's Treaty of Nice. Meanwhile, the dispersion of income widened considerably, as new members' GDP was much lower than incumbents' average. Also, new members have a different history and they have drawn different conclusions from the history than "old members". 5

Table 2: Voting power of the CEE countries under different voting systems

\begin{tabular}{|l|l|l|l|l|l|}
\hline & $\begin{array}{l}\text { Population } \\
(\mathrm{mil})\end{array}$ & $\begin{array}{l}\text { Number of } \\
\text { votes (Nice } \\
\text { treaty) }\end{array}$ & $\begin{array}{l}\text { Share in total } \\
\text { votes (Nice) }\end{array}$ & $\begin{array}{l}\text { Deputies in } \\
\text { the EP }\end{array}$ & $\begin{array}{l}\text { Lisbon } \\
\text { Treaty }\end{array}$ \\
\hline Bulgaria & 7,7 & 10 & $2,9 \%$ & $18(2,3 \%)$ & 1,55 \\
\hline $\begin{array}{l}\text { Czech } \\
\text { Republic }\end{array}$ & 10,2 & 12 & $3,5 \%$ & $24(3,1 \%)$ & 2,08 \\
\hline Estonia & 1,3 & 4 & $1,2 \%$ & $6(0,8 \%)$ & 0,27 \\
\hline Hungary & 10,1 & 12 & $3,5 \%$ & $24(3,1 \%)$ & 2,03 \\
\hline Latvia & 2,3 & 4 & $1,2 \%$ & $9(1,1 \%)$ & 0,46 \\
\hline Lithuania & 3,4 & 7 & $2,0 \%$ & $13(1,7 \%)$ & 0,68 \\
\hline Poland & 38,5 & 27 & $7,8 \%$ & $54(6,9 \%)$ & 7,70 \\
\hline Romania & 21,7 & 14 & $4,1 \%$ & $35(4,5 \%)$ & 4,36 \\
\hline Slovakia & 5,4 & 7 & $2,0 \%$ & $14(1,8 \%)$ & 1,09 \\
\hline Slovenia & 2,0 & 4 & $1,2 \%$ & $7(0,9 \%)$ & 0,41 \\
\hline Croatia & 4,5 & n.a. & & n.a. & n.a. \\
\hline $\begin{array}{l}\text { Share in } \\
\text { total }\end{array}$ & $21 \%$ & $29 \%$ & $29 \%$ & $26,0 \%$ & $20,63 \%$ \\
\hline
\end{tabular}

In 2007, the European Union adopted a new Lisbon Treaty that would change the voting system again. It would make voting power proportional to the country's population and would insert so called double majority whereby any proposal must be supported by $55 \%$ of member states and by $65 \%$ of the EU

\footnotetext{
${ }^{5}$ The Partnership and Co-operation agreement that is supposed to regulate the EU-Russia trade in energy, is a good example of these differences. The agreement was signed in 1997, long before the enlargement. When it was to be re-negotiated, it was first blocked by Poland in 2007 and then by Lithuania in 2008. Both countries demanded much stronger position of the EU vis-à-vis Russia than "old" EU members were prepared to force upon increasingly arduous Russia.
} 
population. These changes would increase power of largest EU members and limit mid-sized countries. The ten CEE countries would see their combined share of votes falling from $29 \%$ to $21 \%$, as nine out of ten countries would see their voting power reduced, sometimes by as much as one half. Only Romania's position would be (marginally) increased. The double majority, on the other hand, would increase importance off small countries, as any thirteen countries, no matter how small, may block any EU initiative, therefore actual "voting power" of small countries would not fall as much as raw voting shares would indicate. For details see Table 2.

Therefore, decision making process in the enlarged European Union was bound to get more complicated. While it is fair to say that the EU is still digesting the enlargements from 2004 and 2007 and it is too early for final conclusions, preliminary data show that decision-making paralysis has failed to materialize in the new EU (see Hagemann, and De Clerck-Sachsse, 2007a). While the transparency of the Councils decisions is not high, there are several attempts to classify its voting history. The following table illustrates, the legislative process in the EU has stabilized. Year 2004 was the most hectic, as almost 600 different legislation acts were approved to accommodate that year's enlargement. In 2005, number of acts approved slipped back to 413, but it rebounded to 516 in 2006 (no data for 2007 available at the moment).

Table 3: Legislative Acts adopted (European Council regulations and directives, European Parliament directives) 2000-2006

\begin{tabular}{|l|l|l|l|l|}
\hline & Regulations & Directives & Decisions & Total \\
\hline 2000 & 189 & 43 & 216 & 448 \\
\hline 2001 & 152 & 58 & 217 & 427 \\
\hline 2002 & 164 & 52 & 217 & 433 \\
\hline 2003 & 191 & 64 & 257 & 512 \\
\hline 2004 & 208 & 52 & 313 & 573 \\
\hline 2005 & 127 & 36 & 250 & 413 \\
\hline 2006 & 199 & 64 & 253 & 516 \\
\hline
\end{tabular}

Source: Plechanovová (2008), Prelex database,

Hagemann and De Clerck-Sachsse (2007b) use a slightly different dataset that, nevertheless, confirms that the legislation pace has not slowed down significantly after the enlargement. According to Hagemann's database, the Councils adopted 160 acts on average in 1999-2003. In 2004, the number 
jumped to 226 and then fell back to 121 in 2005 and stabilized at 217 in 2006. It is, thus, seems fair to conclude that the paralysis of the European Council decision has yet failed to materialize and the enlarged Union seems to be working as smoothly as the EU15 used to.

\section{Voting patterns and emerging coalitions in the Council}

We now turn to the actual decisions adopted by the Council. We will first discuss the voting pattern in all Council meeting and we later shift our attention to the Council for Economic and Financial Affairs.

\section{A. The European Council}

As we have already noted, the openness and transparency of the Councils' decision making is not particularly high. There are several reasons for this state of affairs. First, the very method of the Councils decisions is partly to blame. Decisions are often postponed as long as there is no opposition. So when the final decision is taken, many countries that might have opposed it have been meanwhile placated by some unspecified compensations or they do not formally dissent as not to be seen as troublemakers (see the discussion of dynamic consensus method by the ECB). Secondly, the European Union's institutions do not want to be seen as divisive, so they do not publicize countries' disagreements.

To illustrate the point, the basic statistics might be useful. In the period of May 2004 to the end of 2006, there were 3399 proposals discussed in the Council. Out of these, only 207 proposals (6\% of total) were contested (i.e. a country either abstained from voting or voted against the proposal) by at least one member state (Plechanovová, 2008). A single member country contested 77 cases, remaining 130 were contested by more countries and only six proposals were rejected $(0,18 \%$ of all proposals $)$.

In our following analysis, we use the database collected by Sara Hagemann of the European Policy Centre in Brussels. The database contains details on almost 1,500 votes in the council, out of which 543 took place after the May 2004's enlargement of the European Union (the database runs until the end of October 2007). It also contains information on voting of all member countries, so we may incur several interesting information from it. Out of 543 voting, 431 were unanimously in favor $(80 \%)$. The 132 votes that were contested were 66 contested by at least one member from Central Europe, i.e. Central European countries objected to $15 \%$ of the Commission proposals that were 
submitted to the Council between May 2004 and October 2007. In the following discussion we will largely disregard Bulgaria and Romania who were only 10 months on the Council and both casted a single contest vote, too little to make any reasonable conclusions about their policies.

Among the remaining eight $\mathrm{CEE}$ countries, Poland was the most active opponent: it contested the proposal seventeen times, followed by Slovakia with 11 and Latvia with 10 dissents. On the other extreme Slovenia contested only one proposal during its 42 months on the Council.

Given the small number of contests, it is not surprising that the Central European contest votes were spread thinly and has never accomplished a reversal in the policy. The table shows that, on average, the Czech Republic was most successful in gathering support for its contests (or most willing to support other countries' dissents): it was joined by 3.3 countries when dissenting. Estonia and Slovakia had on average support of 3 countries when dissenting. On the other extreme, Slovenia abstained from a single vote and at that occasion, only Hungary supported it. The issue concerned "Schengen border code" which set standards for movement of persons across borders and Hungary voted against the proposal.

Table also indicates that Slovenia and Hungary are the two countries most out of the sync with the remaining CEE countries: they did not join any contest by any other country from the region. As note above, Slovenia contested only one proposal and it was not supported by any of the EU15 member states, either. Hungary was supported most often - three times - by Greece and twice by Belgium.

The data show that Slovakia and Poland often support each other in dissent: Poland supported $63 \%$ of all Slovak dissents and Slovakia returned the favor in $40 \%$ of Polish dissents. Poland seems also sympathetic to Latvian and Lithuanian contests. Czechs and Estonians spread their contests across all CEE countries more or less equally. 
Table 4: Voting in the European Council

\begin{tabular}{|c|c|c|c|c|c|c|c|c|c|c|c|}
\hline & $B G$ & $C Z$ & $E E$ & $H U$ & $L V$ & $L I$ & $P O$ & $R O$ & $S K$ & $S L$ & $\sum$ \\
\hline$\sum$ & 1 & 9 & 2 & 5 & 10 & 9 & 17 & 1 & 11 & 1 & 66 \\
\hline $\mathrm{BG}$ & & & & 1 & & & & & 1 & & 2 \\
\hline $\mathrm{CZ}$ & & & 1 & & 1 & 2 & 2 & 1 & 1 & & 8 \\
\hline $\mathrm{EE}$ & & 1 & & & 1 & & & & & & 2 \\
\hline HU & 1 & & & & & & & & & 1 & 2 \\
\hline LV & & 1 & 1 & & 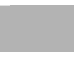 & 2 & 3 & 1 & 1 & & 9 \\
\hline LI & & 2 & & & 2 & & 3 & 1 & 2 & & 10 \\
\hline PO & & 2 & & & 3 & 3 & & & 7 & & 15 \\
\hline RO & & 1 & & & 1 & 1 & & & 1 & & 4 \\
\hline SK & & 1 & & & 1 & 2 & 7 & 1 & & & 12 \\
\hline SL & & & & 1 & & & & & & & 1 \\
\hline AT & & & & & & 1 & 7 & & 7 & & 15 \\
\hline $\mathrm{BE}$ & & 3 & 1 & 2 & 4 & 1 & 5 & & & & 16 \\
\hline CY & 1 & 1 & & 1 & 1 & & 1 & & & & 5 \\
\hline $\mathrm{DN}$ & 1 & 2 & & 1 & 2 & 1 & 1 & 1 & 1 & & 10 \\
\hline FI & & 2 & 1 & & 1 & 1 & & 1 & 1 & & 7 \\
\hline FR & & 1 & & & & & & & & & 1 \\
\hline GE & & & 1 & & 1 & & & & 1 & & 2 \\
\hline GR & 1 & 3 & & 3 & 4 & 1 & 5 & & & & 18 \\
\hline IR & & & & & & & & & 1 & & 1 \\
\hline IT & & & & 1 & & 1 & 2 & & & & 5 \\
\hline LU & & & & & & & & & & & 0 \\
\hline MT & & & & & 1 & 1 & 6 & & 7 & & 15 \\
\hline $\mathrm{NE}$ & & & & & & & & & & & 0 \\
\hline PT & & 6 & 1 & & 1 & & 3 & & & & 11 \\
\hline SP & & 1 & & & & & 1 & & & & 2 \\
\hline SW & & 1 & & 1 & & & & & & & 2 \\
\hline UK & & 1 & & & & & & & 2 & & 3 \\
\hline$*$ & 4 & 3.3 & 3 & 2.2 & 2.4 & 1.9 & 2.7 & 6.0 & 2.9 & 1.0 & \\
\hline
\end{tabular}

*Average number of co-sponsors

The table allows us to analyze positions of the "old members" from the EU15 as well. It is fair to say that none of the countries was an ardent supporter of CEE dissents. Luxembourg and the Netherlands did not support a single contest from a CEE country. The big five EU members - Germany, France, UK, Italy and Spain - were also indifferent to the CEE concerns as they 
casted mere 13 voices in support of any CEE dissent. The most active supporters, if it is the word, was Greece (18 joint dissents with a CEE country), Belgium, Austria and Malta. (Greece actually opposed a decision by a Council only 15 times, but we add each co-vote with a CEE country, even if it was on the same issue.)

These preliminary results cast a doubt on a shared wisdom that the CEE members are supported mostly by the UK and Scandinavian countries. Moreover, analyzing the data a bit more carefully, an unexpected patter emerges. The most trusted partner of the Czech Republic seems to be Portugal that supported 6 out of 9 Czech dissents (67\%). Even more oddly, an improbable group of Poland, Slovakia, Austria and Malta emerges. These countries supported their dissents markedly more often than they supported other countries. More research is however needed before we may determine whether this is only a statistical occurrence or whether there is an MAPS axis within the European Union. 


\section{Box 1: When Greece voted together with CEE:}

Council Regulation amending Regulation (EC) No 2287/2003 as concerns fishing opportunities in Greenland waters

Directive of the European Parliament and of the Council on the approximation of the laws of the Member States relating to electromagnetic compatibility and repealing Directive 89/336/EEC

Council Regulation amending Regulation (EC) No 1260/1999 laying down general provisions on the Structural Funds concerning the extension of the duration of the PEACE programme and the granting of new commitment appropriations

Council Decision fixing the date of application of certain provisions of Regulation (EC) No 871/2004 concerning the introduction of some new functions for the Schengen Information System, including in the fight against terrorism

Directive of the European Parliament and of the Council amending Council Directive 74/408/EEC relating to motor vehicles with regard to the seats, their anchorages and head restraints

Council Regulation concerning the common organisation of the market in hops and repealing Regulations (EEC) No 1696/71, (EEC) No 1037/72, (EEC) No 879/73 and (EEC) No 1981/82 Council Regulations amending Regulation (EC) No 1782/2003 establishing common rules for direct support schemes under the common agricultural policy and establishing certain support schemes for farmers

Council Regulation establishing a temporary scheme for the restructuring of the sugar industry in the European Community and amending Regulation (EC) No 1290/2005 on the financing of the common agricultural policy

Council Decision on Community strategic guidelines for Rural Development (Programming period 2007- 2013)

Council Regulation repealing Regulation (EC) No 3690/93 establishing a Community system laying down rules for the minimum information to be contained in fishing licences

Decision of the European Parliament and of the Council introducing a simplified regime for the control of persons at the external borders, based on the unilateral recognition by the Czech Republic, Estonia, Cyprus, Latvia, Lithuania, Hungary, Malta, Poland, Slovenia and Slovakia of certain documents as equivalent to their national visas for the purposes of transit through their territories

Regulation of the European Parliament and of the Council amending Regulation (EC) No 417/2002 on the accelerated phasing-in of double-hull or equivalent design requirements for single-hull oil tankers Council Regulation on the marketing of the meat of bovine animals age twelve months or less Council Regulation amending Regulation (EC) No 1784/2003 on the common organisation of the market in cereals

Council Regulation on organic production and labelling of organic products and repealing Regulation (EEC) No 2092/91

\section{B. EcoFin - an detailed analysis: Does the CEE have a common agenda?}

In order to structure our dataset further, we look at the role of the CEE countries in various councils. There are nine sectoral Councils plus the European Council that assembles heads of states. Out of the nine Councils of Ministers, six deal mostly with economic agenda. They are:

Council for Economic and Financial Affairs 
Council for Employment, Social Policy, Health and Consumer Affairs

Council for Competitiveness

Council for Transport, Telecommunications and Energy

Council for Agriculture and Fisheries

Council for Environment

The remaining three councils are:

Council for General Affairs and External Relations

Council for Justice and Home Affairs

Council for Education, Youth and Culture

The following table 5 shows distribution of dissent votes by CEE countries. One half of all dissents were casted in the Agriculture Council (34 out of 66) where Poland used its voice 11 times, Latvia 6 times. Other Councils were much less contested and two (Employment and Social Affairs and General and Foreign Affairs councils did not see a single dissent from any CEE country. The details on dissent votes are listed in the Appendix. Perhaps, surprisingly, there was little discussion in the Environment Council, where only 6 dissents were raised by CEE countries and not in one case any two $\mathrm{CEE}$ countries dissented together. This suggests that there is little shared agenda in the Environment Council among the CEE countries.

Our goal in this chapter is to further analyze position of the CEE countries in perhaps the most important Council of Ministers - in the Council for Economic and Financial Affairs, i.e. EcoFin. The Council consists of Finance ministers and convenes every month. It occupies itself with monitoring members' budgetary policy, their economic policy coordination, but it also covers financial markets issues, including regulation and supervision. The EcoFin is also the key player in the annual EU budget adoption. 
Table 5: Voting in the European Council

\begin{tabular}{l|llllllllllll}
\hline & $B G$ & $C Z$ & $E E$ & $H U$ & $L V$ & $L I$ & $P O$ & $R O$ & $S K$ & $S L$ & $\sum$ & \\
\hline$\sum$ & $\mathbf{1}$ & $\mathbf{9}$ & $\mathbf{2}$ & $\mathbf{5}$ & $\mathbf{1 0}$ & $\mathbf{9}$ & $\mathbf{1 7}$ & $\mathbf{1}$ & $\mathbf{1 1}$ & $\mathbf{1}$ & $\mathbf{6 6}$ & \\
\hline $\begin{array}{l}\text { Agri } \\
(187)\end{array}$ & 1 & 3 & 1 & 1 & 6 & 4 & 11 & 0 & 7 & 0 & 34 & $18 \%$ \\
$\begin{array}{l}\text { Env } \\
(41)\end{array}$ & 0 & 0 & 1 & 1 & 1 & 1 & 1 & 0 & 1 & 0 & 6 & $15 \%$ \\
$\begin{array}{l}\text { Comp } \\
\text { et (40) }\end{array}$ & 0 & 2 & 0 & 0 & 0 & 0 & 1 & 0 & 0 & 0 & 3 & $8 \%$ \\
$\begin{array}{l}\text { EcoFi } \\
\text { n (59) }\end{array}$ & 0 & 1 & 0 & 1 & 2 & 1 & 0 & 1 & 1 & 0 & 7 & $12 \%$ \\
$\begin{array}{l}\text { Soc } \\
(25)\end{array}$ & 0 & 0 & 0 & 0 & 0 & 0 & 0 & 0 & 0 & 0 & 0 & $0 \%$ \\
$\begin{array}{l}\text { Trans } \\
(45)\end{array}$ & 0 & 3 & 0 & 0 & 0 & 2 & 2 & 0 & 0 & 0 & 7 & $16 \%$ \\
$\begin{array}{l}\text { Edu } \\
(13)\end{array}$ & 0 & 0 & 0 & 0 & 0 & 0 & 0 & 0 & 1 & 0 & 1 & $8 \%$ \\
$\begin{array}{l}\text { Just } \\
(40)\end{array}$ & 0 & 0 & 0 & 2 & 1 & 1 & 2 & 0 & 1 & 1 & 8 & $20 \%$ \\
$\begin{array}{l}\text { GA } \\
(48)\end{array}$ & 0 & 0 & 0 & 0 & 0 & 0 & 0 & 0 & 0 & 0 & 0 & $0 \%$ \\
\hline & & & & & & & & & & & \\
\hline
\end{tabular}

Notes: Agri - Council for Agriculture and Fisheries

Env - Council for Environment

Compet - Council for Competitiveness

EcoFin - Council for Economic and Financial Affairs

Soc - Council for Employment, Social Policy, Health and Consumer Affairs

Trans - Council for Transport, Telecommunications and Energy

Edu - Council for Education, Youth and Culture

Just - Council for Justice and Home Affairs

GA - Council for General Affairs and External Relations

The decisions of the EcoFin are usually taken by the "qualified majority system", where countries have different number of votes as set by the Nice Treaty (see table 2). Exceptions are fiscal matters that are decided by the unanimity principle. The EcoFin discussions are among the livelier and open among the Councils. The EcoFin famously failed to upheld reprimand to Germany and France when the two were castigated by the European 
Commission for breaching the Stability and Growth Pact rules in 2004 and 2005.

However, the CEE's activity in the Economic and Finance Affairs is surprisingly low, as long as we measure it by dissenting votes. In the period May 2004-December 2007, there were 59 decisions taken in this area. Bulgaria, Estonia, Slovenia and Poland did not challenge any of these. Latvia challenged two decisions and remaining countries resorted to a dissent just once. Most of this dissent concentrated to the Council regulation regarding a temporary scheme for restructuring the sugar industry (see http://register.consilium.europa.eu/pdf/en/07/st13/st13661-ad01.en07.pdf) when the Czech Republic, Slovakia (plus Finland and Denmark) voted against the proposal and Latvia, Lithuania and Romania abstained. In this case, thus, five out of ten new members contested the regulation, but to no avail, as the Council adopted it anyway.

In order to get a more detailed analysis of the EcoFin decision making, we further analyzed minutes of the EcoFin as they are published by the Czech Ministry of Finance (http://www.mfcr.cz/cps/rde/xchg/mfcr/xsl/ecofin.html). As these information are not strictly representative (and are available in Czech only), they should be interpreted carefully. We should also note that disagreements are often voiced informally we had to use our discretion in selecting these "contentious" issues and other analyses may identify other sets of issues. On the other hand, our analysis allows an insight into informal and formal discussion before the vote is taken, so they may reflect countries' positions before the "dynamic consensus process" is put into motion.

The table in the appendix 2 summarizes main contentious points that were debated at the EcoFin since January 2007 until spring of 2008. We have identified 26 disagreements where one or more countries objected to the proposal or raised serious doubts about its merits. Some of the issues emerge repeatedly (the navigation system Galileo or corporate tax base harmonization), some are dealt with very quickly (the EBRD presidency).

Some preliminary analysis: new member states were active in 14 out of 26 disputes. Poland was the most frequent participant: it was involved in eight discussions. On the other hand Bulgaria and Romania did participate only once. We may thus say that the EU10 do take position in the EcoFin discussions and are not afraid of raising their voice. 
However, our analysis seems to support other authors as we do not find any significant cohesion among the EU10. In most cases the EU10 were either neutral (i.e. there were no positions taken by any of the EU10 countries) or they were split. Poland often disagreed with the Czech Republic - Poland was in favor of an initiative limiting sovereign funds investment, the Czechs were against. Czechs supported pollution trading while Poland opposed it. Hungary was the only EU10 country supporting (the Hungarian...) Commissioner Kovacs in his attempts to consolidate tax base for multinational corporations in the EU. Hungary and the Czech Republic clashed over the EBRD presidency (only to be steamrolled by Germans). We could not identify a single issue where the EU10 would take a common position and win. The closest they came was in January 2007 when they helped to kill the Commission proposal to set national targets for eliminating excessive administrative procedures. The Czech Republic, Latvia, Lithuania, Slovenia and Estonia joined Belgium, the Netherlands and Portugal and the European Commission backtracked.

Therefore, there appears to be no common agenda among the new member states in the EcoFin. According to the anecdotic evidence, the new member states are similarly inefficient in other Councils, namely in Agriculture and in Environment, even though these two Councils distribute most of the European Union's budget.

This passivity and lack of common stand may be caused by many factors. The new member states may not believe that the EcoFin decision will be relevant for them, so they do not bother to dispute them. The may also negotiate before the EcoFin discusses the matter and "piggy-back" on some large country opposition. Or, the new member state might believe that their opposition will not change the outcome anyway.

\section{Conclusions}

Membership of the ten Central European countries in the European Union, while still recent, has been an overall success. The economic performance during the membership has been, so far, very robust. The region benefited from increased investments, exploding trade and, albeit limited, labor mobility. GDP growth rates have stabilized for most countries in unheard-of region of 5-7\% annually, inflation was subdued and unemployment began to slowly fall. 
It is, of course, difficult to determine whether this economic success is a direct consequence of the EU membership. Other European countries that had not joined the EU grew robustly as well (Romania, Bulgaria, but also Albania, Armenia, Georgia or Montenegro). However, the CEE economies definitely enjoyed a positive supply shock before and during the EU membership, as its stock of capital increased; the legal framework was standardized and familiarized to multinational firms. As a result of combination of factors, all countries in region experienced stable and positive economic growth, relatively low inflation and increased productivity, for the first time since the beginning of transition.

However, with these initial effects slowly dissipating, the future developments of the CEE's and indeed the whole EU's economic policies depend to a large extent on the introduction of further reforms. European economies are still hampered by high taxes, excessive bureaucracy, limited mobility of labor and barriers to free movements of workers or firms in several major areas (services being the most evident example).

Introduction of economic reforms is challenging within one country framework - witness conflicts in France, Italy, Czech Republic or Hungary, to mention only the most recent. Implementation of reforms in a Union of 27 nations is extremely difficult. The European Union is a club of increasingly heterogeneous countries: from high spending Sweden and France to lean Estonia or Ireland, from agriculture oriented Romania and Greece to financial services dominated Britain.

It is obvious that finding a consensus in such a heterogeneous group of countries is extremely difficult. One way to deal with the heterogeneity is to streamline decision-making processes and limit voting power of smaller countries. While the European Union tries to do exactly this in its Lisbon Treaty, it will never, nor should it eliminate frictions and ability of small countries (or their coalitions) to block important decisions.

The remaining possibility to introduce reforms within the European Union is coalition building and relentless and long-term propagation of reforms. Our paper argued that Central and East European members of the EU have high stakes in reform agenda and in such coalition building. Their economies are still less developed that the "old" EU members. The CEE countries have also undergone major reforms in last two decades and their experiences with reforms are, with all caveats, positive. They, thus, may be more prepared for further push and they should be natural partners. 
Our analysis, though, shows that the CEE countries do not propagate similar agenda within the EU, nor that they support each other consistently, perhaps with exemption of the nascent Polish-Slovak coalition in many Council decisions. Should the CEE countries become agents of the European Union future reforms, they have to come together and become more unified in their agenda and voting even if it means voting against some powerful "old" member countries.

\section{Literature}

Alesina, A. and R. Wacziarg (1999), Is Europe Going Too Far?, NBER WP 6883, January 1999.

Baldwin, Richard and Charles Wyplosz (2006): The Economics of European Integration, $2^{\text {nd }}$ Edition, McGraw Hill.

Berger (2002) The ECB and Euro-Area Enlargement, IMF Working Paper http://www.imf.org/external/pubs/ft/wp/2002/wp02175.pdf

Collignon S. (2005), The Three Source of Legitimacy for European Fiscal Policy”, at http://www.arena.uio.no/cidel/WorkshopStockholm/Collignon.pdf

Eijffinger, Sylvester C.W. and Jakob de Hahn (2000): European Monetary and Fiscal Policy, Oxford University Press.

Frenkel, M. and R. Fendel (2003): The new ECB voting system: Some room for improvement, Intereconomics, volume: 38 (2003), isme 6, pp 334-338

Grauwe, Paul de: Economics of Monetary Union (2005), $6^{\text {th }}$ Edition, Oxford University Press.

Hagemann, Sara, and De Clerck-Sachsse, Julia. (2007a) Decision-making in the Enlarged Council of Ministers: Evaluating the Facts. CEPS Policy Brief, No. 119, 28 January 2007

Hagemann, Sara, and De Clerck-Sachsse, Julia. (2007b): Old Rules, New Game: Decision-making in the Council of Ministers after the 2004 Enlargement, CEPS Special Report, March 2007

Mayhew, A. (2000): Enlargement of the EU: An Analysis of the negotiations http://www.sussex.ac.uk/sei/documents/wp39.pdf

Moravcsik, A. (2002): In Defence of the "Democratic Deficit, Journal of Common Market Studies 2002, pp. 603-24

Plechanovová, B. (2008): The EU Council Enlarged: North-South-East or CorePeriphery?, mimeo.

Tupy, Marian L. (2003): EU Enlargement - Costs, Benefits and Strategies for CEE Countries, CATO Policy Analysis No. 489, Washington D.C.

Wallace, Hellen, William Wallace and Mark Pollack (2005): Policy-Making in the European Union, Oxford University Press. 


\section{Appendix 1: Voting in the Council - Contested votes in May 2004-October 2007}

\section{1) Environment Council:}

41 decisions

Contests:

Poland: 1

Decision of the European Parliament and of the Council concerning the Seventh Framework Programme of the European Community for research, technological development and demonstration activities (2007-2013)

Czech Rep: 0

Hungary: 1

Council Regulation on organic production and labelling of organic products and repealing Regulation (EEC) No 2092/91)

Slovakia: 1 (as Poland)

Lithuania: 1

Regulation of the European Parliament and of the Council laying down the rules for the participation of undertakings, research centres and universities in actions under the Seventh Framework Programme and for the dissemination of research results (2007-2013)

Latvia: 1

Proposal for a Regulation of the European Parliament and the Council on the law applicable to non-contractual obligations ("ROME II"))

Slovenia: 0

Estonia: 1 (as Latvia)

Bulgaria: 0

Romania: 0

Note: no country contested the most controversial decision on regulation of chemicals - REACH (Regulation of the European Parliament and of the Council concerning the registration, evaluation, authorization and restriction of chemicals $(\mathrm{REACH})$, establishing a European Chemicals Agency, amending Directive 1999/45/EC and repealing Council Regulation (EEC) No 793/93 and Commission Regulation (EC) No 1488/94 as well as Council Directive 76/769/EEC and Commission Directives 91/155/EEC, 93/67/EEC, 93/105/EC and 2000/21/EC).

\section{2) Agriculture and Fisheries Council:}

187 decisions

Contests:

Poland: 11

Council Regulation concerning the common organisation of the market in hops and repealing 
Regulations (EEC) No 1696/71, (EEC) No 1037/72, (EEC) No 879/73 and (EEC) No 1981/82 Council Regulations amending Regulation (EC) No 1782/2003 establishing common rules for direct support schemes under the common agricultural policy and establishing certain support schemes for farmers

Council Regulation establishing a temporary scheme for the restructuring of the sugar industry in the European Community and amending Regulation (EC) No 1290/2005 on the financing of the common agricultural policy

Council Decision on Community strategic guidelines for Rural Development (Programming period 2007- 2013)

Council Decisions on the Specific Programmes ("Cooperation", "Ideas", "People", Capacities, "JRCEC", "Euratom" and "JRC-Euratom") implementing the Seventh Framework Programmes - EC (20072013) and EURATOM (2007-2011)

Council Decision concerning the Specific Programme "Cooperation" implementing the Seventh Framework Programme of the European Community (2007-2013) for research, technological development and demonstration activities

Council Decision concerning the Specific Programme "Ideas" implementing the Seventh Framework Programme of the European Community (2007-2013) for research, technological development and demonstration activities

Council Decision concerning the Specific Programme "People" implementing the Seventh Framework Programme of the European Community (2007-2013) for research, technological development and demonstration activities

Council Decision concerning the Specific Programme "Capacities" implementing the Seventh

Framework Programme of the European Community (2007-2013) for research, technological development and demonstration activities

Council Decision concerning the Specific Programme to be carried out by means of direct actions by the Joint Research Centre under the Seventh Framework Programme of the European Community (20072013) for research, technological development and demonstration activities

Council Regulation amending Regulation (EC) No 1868/94 establishing a quota system in relation to the production of potato starch

Czech Rep: 3

Decision of the European Parliament and of the Council establishing a multiannual Community programme to make digital content in Europe more accessible, usable and exploitable Council Regulation concerning the common organisation of the market in hops and repealing Regulations (EEC) No 1696/71, (EEC) No 1037/72, (EEC) No 879/73 and (EEC) No 1981/82 Council Regulation repealing Regulation (EC) No 3690/93 establishing a Community system laying down rules for the minimum information to be contained in fishing licences

Hungary: 1

Council Regulation amending Regulation (EC) No 1784/2003 on the common organisation of the market in cereals 


\section{Slovakia: 7}

Council Decisions on the Specific Programmes ("Cooperation", "Ideas", "People", Capacities, "JRCEC", "Euratom" and "JRC-Euratom") implementing the Seventh Framework Programmes - EC (20072013) and EURATOM (2007-2011)

Council Decision concerning the Specific Programme "Cooperation" implementing the Seventh Framework Programme of the European Community (2007-2013) for research, technological development and demonstration activities

Council Decision concerning the Specific Programme "Ideas" implementing the Seventh Framework Programme of the European Community (2007-2013) for research, technological development and demonstration activities

Council Decision concerning the Specific Programme "People" implementing the Seventh Framework Programme of the European Community (2007-2013) for research, technological development and demonstration activities

Council Decision concerning the Specific Programme "Capacities" implementing the Seventh

Framework Programme of the European Community (2007-2013) for research, technological

development and demonstration activities

Council Decision concerning the Specific Programme to be carried out by means of direct actions by the Joint Research Centre under the Seventh Framework Programme of the European Community (20072013) for research, technological development and demonstration activities

Council Regulation amending Regulation (EEC) No 1883/78 laying down general rules for the financing of interventions by the European Agricultural Guidance and Guarantee Fund, Guarantee Section

\section{Lithuania: 4}

Council Regulation amending Regulation (EC) No 1260/1999 laying down general provisions on the Structural Funds concerning the extension of the duration of the PEACE programme and the granting of new commitment appropriations

Council Regulation laying down the rules for the participation of undertakings, research centres and universities in actions under the Seventh Framework Programme of the European Atomic Energy Community and for the dissemination of research results (2007-2011)

Council Decisions on the Specific Programmes ("Cooperation", "Ideas", "People", Capacities, "JRCEC", "Euratom" and "JRC-Euratom") implementing the Seventh Framework Programmes - EC (20072013) and EURATOM (2007-2011)

Council Regulation amending Regulation (EC) No 1868/94 establishing a quota system in relation to the production of potato starch

Latvia: 6

Council Regulation amending Regulation (EC) No 1260/1999 laying down general provisions on the Structural Funds concerning the extension of the duration of the PEACE programme and the granting of new commitment appropriations

Regulation of the European Parliament and of the Council amending Regulation (EC) No 999/2001

laying down rules for the prevention, control and eradication of certain transmissible spongiform encephalopathies as regards the extension of the period for transitional measures 
Council Regulations amending Regulation (EC) No 1782/2003 establishing common rules for direct support schemes under the common agricultural policy and establishing certain support schemes for farmers

Council Regulation establishing a temporary scheme for the restructuring of the sugar industry in the European Community and amending Regulation (EC) No 1290/2005 on the financing of the common agricultural policy

Council Decision on Community strategic guidelines for Rural Development (Programming period 2007- 2013)

Council Regulation amending and correcting Regulation (EC) No 1782/2003 establishing common rules for direct support schemes under the common agricultural policy and establishing certain support schemes for farmers and amending Regulation (EC) No 1698/2005 on support for rural development by the European Agricultural Fund for Rural Development (EAFRD)

Slovenia: 0

Estonia: 1

Council Regulation repealing Regulation (EC) No 3690/93 establishing a Community system laying down rules for the minimum information to be contained in fishing licences

\section{Bulgaria: 1}

Council Regulation amending Regulation (EC) No 1784/2003 on the common organisation of the market in cereals

Romania: 0

\section{3) Competitiveness Council}

40 decisions

Poland: 1

Council Regulation amending Regulation (EC) No 2287/2003 as concerns fishing opportunities in Greenland waters

\section{Czech Rep: 2}

Council Regulation amending Regulation (EC) No 2287/2003 as concerns fishing opportunities in Greenland waters

Council Decision authorising Sweden to apply a reduced rate of taxation to electricity consumed by households and service sector companies situated in certain areas in the north of Sweden in accordance with Article 19 of Directive 2003/96/EC

Hungary: 0

Slovakia: 0

Latvia: 0 
Lithuania: 0

Slovenia: 0

Estonia: 0

Bulgaria: 0

Romania: 0

4) Economic and Financial Affairs Council (EcoFin)

52 decisions

Poland: 0

Czech Rep: 1

Council Regulation amending Regulation (EC) No 318/2006 on the common organisation of the markets in the sugar sector

Hungary: 1

Regulation of the European Parliament and of the Council amending Regulation (EC) No $2037 / 2000$ as regards the base year for the allocation of quotas of hydrochlorofluorocarbons with respect to the Member States that acceded on May 2004

Slovakia: 1 (as Czechs)

Lithuania: 1 (dtto)

Latvia: 2(dtto, plus

Council Regulation laying down rules for voluntary modulation of direct payments provided for in Regulation (EC) No 1782/2003 establishing common rules for direct support schemes under the common agricultural policy and establishing certain support schemes for farmers, and amending Regulation (EC) No 1290/2005)

Estonia: 0

Slovenia: 0

Bulgaria: 0

Romania: 1 (as Czechs)

5) Employment, Social Policy, Health and Consumer Affairs Council

25 decisions

Poland: 0

Czechs: 0

Hungary: 0

Slovakia: 0

Lithuania: 0

Latvia: 0 
Estonia: 0

Slovenia: 0

Bulgaria: 0

Romania: 0

\section{6) Transport, Telecommunications and Energy Council}

45 decisions

Poland: 2

Council Regulation fixing the fishing opportunities and associated conditions for certain fish stocks and groups of fish stocks applicable in the Baltic Sea for 2007

Council Regulation fixing the fishing opportunities and associated conditions for certain fish stocks and groups of fish stocks applicable in the Baltic Sea for 2007

Czechs: 3

Regulation of the European Parliament and of the Council on cooperation between national authorities responsible for the enforcement of consumer protection laws ("Regulation on consumer protection cooperation")

Directive of the European Parliament and of the Council on services in the internal market

Directive of the European Parliament and of the Council on services in the internal market

Hungary: 0

Slovakia: 0

Lithuania: 2

Directive of the European Parliament and of the Council on services in the internal market Decision of the European Parliament and of the Council establishing for the period 2007-2013 the programme "Europe for Citizens" to promote active European citizenship

Latvia: 0

Slovenia: 0

Bulgaria: 0

Romania: 0

7) Education Council

13 decisions

Poland: 0

Czechs: 0

Hungary: 0

Slovakia: 1 
Lithuania: 0

Latvia: 0

Estonia: 0

Slovenia: 0

Bulgaria: 0

Romania: 0

8) Justice and Home Affairs

40 decisions

Poland: 2

Czechs: 0

Hungary: 2

Slovakia: 1

Lithuania: 1

Latvia: 1

Estonia: 0

Slovenia: 1

Bulgaria: 0

Romania: 0

9) General Affairs and External Relations

48 decisions

Poland: 0

Czechs: 0

Hungary: 0

Slovakia: 0

Lithuania: 0

Latvia: 0

Estonia: 0

Slovenia: 0

Bulgaria: 0

Romania: 0 
Appendix 2: Discontent in the EcoFin 2007-2008

\begin{tabular}{|c|c|c|c|c|}
\hline Date & Issue & Troublemaker & $\begin{array}{l}\text { CEE } \\
\text { position }\end{array}$ & Who wins \\
\hline \multirow[t]{5}{*}{$\begin{array}{l}\text { March } \\
2008\end{array}$} & $\begin{array}{l}\text { Economic plans } \\
\text { BEPG (Broad } \\
\text { Economic } \\
\text { Policy } \\
\text { Guidelines) }\end{array}$ & $\begin{array}{l}\text { Luxembourg, } \\
\text { Italy }\end{array}$ & $\begin{array}{l}\text { Split: } \\
\text { CZ } \\
\text { opposes, } \\
\text { other } \\
\text { neutral }\end{array}$ & $\begin{array}{l}\mathrm{G}, \quad \mathrm{Es}, \\
\mathrm{UK}, \mathrm{CZ}\end{array}$ \\
\hline & Sovereign funds & Poland & Split & $?$ \\
\hline & Taxes & $\mathrm{G}, \mathrm{AU}$ & neutral & $\begin{array}{l}\text { It, F, Fi, } \\
\text { Pt }\end{array}$ \\
\hline & $\begin{array}{ll}\begin{array}{l}\text { Taxes } \\
\text { savings }\end{array} & \text { on } \\
\end{array}$ & Luxembourg & neutral & $?$ \\
\hline & EBRD & $\mathrm{CZ}, \mathrm{Hu}$ & Split & Germany \\
\hline \multirow{2}{*}{$\begin{array}{l}\text { February } \\
2008\end{array}$} & Budget deficits & $\mathrm{F}$ & neutral & $\mathrm{F}$ \\
\hline & $\begin{array}{l}\text { Pollution } \\
\text { trading }\end{array}$ & all & $\begin{array}{l}\text { Split: } \\
\text { CZ } \\
\text { Po and } \\
\text { Ro }\end{array}$ & $\begin{array}{ll}\mathrm{F}, & \mathrm{EE}, \\
\mathrm{HU} & \text { and } \\
\mathrm{CZ} & \end{array}$ \\
\hline $\begin{array}{l}\text { January } \\
2008\end{array}$ & $\begin{array}{l}\text { Financial } \\
\text { services }\end{array}$ & UK, NL & neutral & postponed \\
\hline \multirow[t]{4}{*}{$\begin{array}{l}\text { December } \\
2007\end{array}$} & $\begin{array}{l}\text { Financial } \\
\text { regulation }\end{array}$ & $\begin{array}{l}\text { Italy vs. UK, } \\
\text { AU }\end{array}$ & neutral & UK \\
\hline & Insurance sector & It, LV, G, Po & split & $\mathrm{pp}$ \\
\hline & VAT & Lux & neutral & Lux \\
\hline & Lower VAT & Pol & $\begin{array}{l}\text { Split Po } \\
\text { vs. S1 }\end{array}$ & $\mathrm{G}, \mathrm{Sl}$ \\
\hline \multirow{4}{*}{$\begin{array}{l}\text { November } \\
07\end{array}$} & Labor migration & Slovenia & & $?$ \\
\hline & VAT on IT & Lux & $\begin{array}{l}\text { Split: } \\
\text { CZ and } \\
\text { SL }\end{array}$ & Lux loses \\
\hline & $\begin{array}{l}\text { Carbon tax on } \\
\text { cars }\end{array}$ & $\mathrm{G}, \mathrm{I}, \mathrm{UK}, \mathrm{CZ}$ & $\begin{array}{l}\text { All } \\
\text { against }\end{array}$ & $\mathrm{pp}$ \\
\hline & Gallieleo & $\mathrm{AU}, \mathrm{DK}$ & neutral & $\mathrm{G}$ \\
\hline $\begin{array}{l}\text { October } \\
2007\end{array}$ & Galileo & $\mathrm{G}$ & neutral & $\mathrm{pp}$ \\
\hline
\end{tabular}




\begin{tabular}{|l|l|l|l|l|}
\hline July 2007 & galileo & G, UK & neutral & pp \\
\hline & IMF & Pol & split & F \\
\hline June 2007 & $\begin{array}{l}\text { Consolidation } \\
\text { of corp tax base }\end{array}$ & UK & split & pp \\
\hline May 2007 & Reverse-charge & F, I & $\begin{array}{l}\text { Split, } \\
\text { LV for }\end{array}$ & F \\
\hline $\begin{array}{l}\text { April } \\
2007\end{array}$ & $\begin{array}{l}\text { Financial } \\
\text { March } \\
2007\end{array}$ & POl & Split & Po loses \\
\hline $\begin{array}{l}\text { February } \\
2007\end{array}$ & SGP & Pol & Split & Po loses \\
\hline & Consolidation... & $\begin{array}{l}\text { G, AU, Sl, } \\
\text { Hu }\end{array}$ & $\begin{array}{l}\text { Split: Sl, } \\
\text { Hu vs. } \\
\text { LV, LT, } \\
\text { CZ }\end{array}$ & \\
\hline $\begin{array}{l}\text { January } \\
2007\end{array}$ & CCCTB & Ir, SW, LV & Split & pp \\
\hline & KIP - taxes & $\begin{array}{l}\text { LA, PO, } \\
\text { CZ,SW, UK }\end{array}$ & split & $\begin{array}{l}\text { LA and } \\
\text { others }\end{array}$ \\
\hline & EU8, Pt, NL & $\begin{array}{l}\text { Unified } \\
\text { (HU?) }\end{array}$ & win \\
\hline
\end{tabular}




\section{CESifo Working Paper Series}

for full list see www.cesifo-group.org/wp

(address: Poschingerstr. 5, 81679 Munich, Germany, office@cesifo.de)

2393 António Afonso and Christophe Rault, 3-Step Analysis of Public Finances Sustainability: the Case of the European Union, September 2008

2394 Betsey Stevenson and Justin Wolfers, Economic Growth and Subjective Well-Being: Reassessing the Easterlin Paradox, September 2008

2395 Bernhard Eckwert and Itzhak Zilcha, Private Investment in Higher Education: Comparing Alternative Funding Schemes, September 2008

2396 Øystein Foros, Hans Jarle Kind and Jan Yngve Sand, Slotting Allowances and Manufacturers' Retail Sales Effort, September 2008

2397 Mohammad Reza Farzanegan, Illegal Trade in the Iranian Economy: Evidence from a Structural Model, September 2008

2398 Olivier Bos, Charity Auctions for the Happy Few, September 2008

2399 Robert S. Chirinko and Debdulal Mallick, The Marginal Product of Capital: A Persistent International Puzzle, September 2008

2400 Ben D'Exelle and Arno Riedl, Elite Capture, Political Voice and Exclusion from Aid: An Experimental Study, September 2008

2401 Torben M. Andersen and Joydeep Bhattacharya, On Myopia as Rationale for Social Security, September 2008

2402 Fabienne Llense, French CEO Compensations: What is the Cost of a Mandatory Upper Limit?, September 2008

2403 Valentina Bosetti, Carlo Carraro, Alessandra Sgobbi and Massimo Tavoni, Delayed Action and Uncertain Targets. How Much Will Climate Policy Cost?, September 2008

2404 Robert G. Chambers, Rolf Färe, Shawna Grosskopf and Michael Vardanyan, Generalized Quadratic Revenue Functions, September 2008

2405 Leonidas Enrique de la Rosa, Overconfidence in a Career-Concerns Setting, September 2008

2406 Marcus Drometer and Johannes Rincke, The Design of Political Institutions: Electoral Competition and the Choice of Ballot Access Restrictions in the United States, September 2008

2407 Markku Lanne and Helmut Lütkepohl, Stock Prices and Economic Fluctuations: A Markov Switching Structural Vector Autoregressive Analysis, September 2008 
2408 Thomas L. Brewer, International Energy Technology Transfers for Climate Change Mitigations, September 2008

2409 Alexander Kemnitz, Native Welfare Losses from High Skilled Immigration, September 2008

2410 Xavier Vives, Strategic Supply Function Competition with Private Information, September 2008

2411 Fabio Padovano and Roberto Ricciuti, The Political Competition-Economic Performance Puzzle: Evidence from the OECD Countries and the Italian Regions, September 2008

2412 Joan Costa-Font and Mireia Jofre-Bonet, Body Image and Food Disorders: Evidence from a Sample of European Women, September 2008

2413 Thorsten Upmann, Labour Unions - To Unite or to Separate?, October 2008

2414 Sascha O. Becker and Ludger Woessmann, Luther and the Girls: Religious Denomination and the Female Education Gap in $19^{\text {th }}$ Century Prussia, October 2008

2415 Florian Englmaier and Stephen Leider, Contractual and Organizational Structure with Reciprocal Agents, October 2008

2416 Vittorio Daniele and Ugo Marani, Organized Crime and Foreign Direct Investment: The Italian Case, October 2008

2417 Valentina Bosetti, Carlo Carraro, Alessandra Sgobbi and Massimo Tavoni, Modelling Economic Impacts of Alternative International Climate Policy Architectures. A Quantitative and Comparative Assessment of Architectures for Agreement, October 2008

2418 Paul De Grauwe, Animal Spirits and Monetary Policy, October 2008

2419 Guglielmo Maria Caporale, Christophe Rault, Robert Sova and Anamaria Sova, On the Bilateral Trade Effects of Free Trade Agreements between the EU-15 and the CEEC-4 Countries, October 2008

2420 Yin-Wong Cheung and Daniel Friedman, Speculative Attacks: A Laboratory Study in Continuous Time, October 2008

2421 Kamila Fialová and Ondřej Schneider, Labour Market Institutions and their Effect on Labour Market Performance in the New EU Member Countries, October 2008

2422 Alexander Ludwig and Michael Reiter, Sharing Demographic Risk - Who is Afraid of the Baby Bust?, October 2008

2423 Doina Maria Radulescu and Michael Stimmelmayr, The Welfare Loss from Differential Taxation of Sectors in Germany, October 2008 
2424 Nikolaus Wolf, Was Germany ever United? Evidence from Intra- and International Trade 1885 - 1933, October 2008

2425 Bruno S. Frey, David A. Savage and Benno Torgler, Noblesse Oblige? Determinants of Survival in a Life and Death Situation, October 2008

2426 Giovanni Facchini, Peri Silva and Gerald Willmann, The Customs Union Issue: Why do we Observe so few of them?, October 2008

2427 Wido Geis, Silke Uebelmesser and Martin Werding, Why go to France or Germany, if you could as well go to the UK or the US? Selective Features of Immigration to four major OECD Countries, October 2008

2428 Geeta Kingdon and Francis Teal, Teacher Unions, Teacher Pay and Student Performance in India: A Pupil Fixed Effects Approach, October 2008

2429 Andreas Haufler and Marco Runkel, Firms' Financial Choices and Thin Capitalization Rules under Corporate Tax Competition, October 2008

2430 Matz Dahlberg, Heléne Lundqvist and Eva Mörk, Intergovernmental Grants and Bureaucratic Power, October 2008

2431 Alfons J. Weichenrieder and Tina Klautke, Taxes and the Efficiency Costs of Capital Distortions, October 2008

2432 Andreas Knabe and Ronnie Schöb, Minimum Wage Incidence: The Case for Germany, October 2008

2433 Kurt R. Brekke and Odd Rune Straume, Pharmaceutical Patents: Incentives for R\&D or Marketing?, October 2008

2434 Scott Alan Carson, Geography, Insolation, and Institutional Change in $19^{\text {th }}$ Century African-American and White Stature in Southern States, October 2008

2435 Emilia Del Bono and Daniela Vuri, Job Mobility and the Gender Wage Gap in Italy, October 2008

2436 Marco Angrisani, Antonio Guarino, Steffen Huck and Nathan Larson, No-Trade in the Laboratory, October 2008

2437 Josse Delfgaauw and Robert Dur, Managerial Talent, Motivation, and Self-Selection into Public Management, October 2008

2438 Christian Bauer and Wolfgang Buchholz, How Changing Prudence and Risk Aversion Affect Optimal Saving, October 2008

2439 Erich Battistin, Clara Graziano and Bruno Parigi, Connections and Performance in Bankers' Turnover: Better Wed over the Mixen than over the Moor, October 2008 
2440 Erkki Koskela and Panu Poutvaara, Flexible Outsourcing and the Impacts of Labour Taxation in European Welfare States, October 2008

2441 Marcelo Resende, Concentration and Market Size: Lower Bound Estimates for the Brazilian Industry, October 2008

2442 Giandomenico Piluso and Roberto Ricciuti, Fiscal Policy and the Banking System in Italy. Have Taxes, Public Spending and Banks been Procyclical in the Long-Run? October 2008

2443 Bruno S. Frey and Katja Rost, Do Rankings Reflect Research Quality?, October 2008

2444 Guglielmo Maria Caporale, Antoaneta Serguieva and Hao Wu, Financial Contagion: Evolutionary Optimisation of a Multinational Agent-Based Model, October 2008

2445 Valentina Bosetti, Carlo Carraro and Massimo Tavoni, Delayed Participation of Developing Countries to Climate Agreements: Should Action in the EU and US be Postponed?, October 2008

2446 Alexander Kovalenkov and Xavier Vives, Competitive Rational Expectations Equilibria without Apology, November 2008

2447 Thiess Buettner and Fédéric Holm-Hadulla, Cities in Fiscal Equalization, November 2008

2448 Harry H. Kelejian and Ingmar R. Prucha, Specification and Estimation of Spatial Autoregressive Models with Autoregressive and Heteroskedastic Disturbances, November 2008

2449 Jan Bouckaert, Hans Degryse and Thomas Provoost, Enhancing Market Power by Reducing Switching Costs, November 2008

2450 Frank Heinemann, Escaping from a Combination of Liquidity Trap and Credit Crunch, November 2008

2451 Dan Anderberg, Optimal Policy and the Risk Properties of Human Capital Reconsidered, November 2008

2452 Christian Keuschnigg and Evelyn Ribi, Outsourcing, Unemployment and Welfare Policy, November 2008

2453 Bernd Theilen, Market Competition and Lower Tier Incentives, November 2008

2454 Ondřej Schneider, Voting in the European Union - Central Europe's Lost Voice, November 2008 